\title{
Directing Passions in New Delhi's World of Fashion
}

On the Power of Ritual and 'Illusions without Owners'

\section{Tereza Kuldova}

University of Oslo, Norway

\begin{abstract}
Grounded in long-term ethnographic fieldwork in New Delhi's fashion industry, this article explores the pressing question on the designer's mind, namely: how to I align the desires of others with my (master)-desire? This question points us towards an investigation of how people's affects are mobilized and directed through commercial rituals such as fashion shows set within hyper-designed theatrical play-spheres. Translating the invisible or covert mobilization of affects into profit has been on the mind of advertisers for the last decade. However, analysing such deliberately covert strategies of capture employed in two cases - JJ Valaya's haute couture shows and Nitin Bal Chauhan's youth brand - we realize that it is precisely their failure at being covert that makes them effective; clients know well about them. Robert Pfaller's theory of 'illusions without owners' can throw some light here on why clients passionately embrace the desire of capital precisely against their better knowledge.
\end{abstract}

\section{Keywords}

Indian fashion, affect, ritual, Spinoza, collective effervescence, Robert Pfaller, illusions without owners

\section{Corresponding author:}

Tereza Kuldova, Faculty of Humanities, University of Oslo, Norway.

Email: tereza.kuldova@iakh.uio.no 
Accepted for publication in Thesis Eleven, OnlineFirst July 2015 (printed February 2016), currently waiting for copy-edit

'Passionate exo-determination is our irremissible condition'

(Lordon, 2014: 159)

Spinoza famously insisted that to exist is to desire, that we are beings driven by our desires, active in and activated by their relentless pursuit - in conatus, desire and being collapse into each other. Mobilization of affects that redirects the conatus, and thus the very desire to act, is then the goal of all operations of power - from politics to advertising or PR. As an elite fashion designer in New Delhi remarked, 'our business runs on desire, we create it, we fuel it and we direct it'. Later adding that 'we have to convince them [customers] that the desire is theirs, it has to look authentic and spontaneous'. The underlying injunction here is: 'be authentic, be spontaneous and desire it yourself, but only the way I tell you to'. The question that torments (more or less consciously) most designers, as any other capitalist or politician, is therefore: how can I align the desires of others with my (master)-desire?

\section{The Indian Fashion Industry and Strategies of Capture}

Fashion is primarily a business (Entwistle, 2009; Hoskins, 2014), a business that runs on desires, hopes and fantasies rather than on simple seductions of material textures; only secondarily is fashion a creative profession for selected few. The Indian fashion industry, initially modelled upon the example of the fashion systems of Paris, London and New York, is barely thirty years old ${ }^{2}$. Most designers cater predominantly to the Indian market, followed by the Gulf countries, Russia, Singapore and western countries with Indian diaspora. The financial crisis of 2008 became a turning point when many designers pulled out of western markets and rejected the idea of seeking recognition in Paris, Milan and New York that they were after in the 90s and early 2000s. Instead, they re-oriented themselves at the growing Indian upper-middle class and elite clientele. This shift coincided with the rise of nationalist sentiments, pride and belief in India's future superpowerdom (Kuldova, 2014a). Most designers have jumped, in one way or the other, on the wave of 'artistic nationalism' (Ciotti, 2012), thus selling varieties of the 'essence of Indianness' to privileged Indians. Nationalist myths have a good record of capturing the people's power to act, which makes them a conscious favourite among the designers. Being a young industry, it is also far more centred on the persona of the designer, who is often one with the brand, than is the case for globally well-established western fashion brands. While in India as in the West, celebrating designers as unique creative artists systematically obscures the fact that fashion is a cut throat business, while pushing into invisibility actual relations of production and complex distributions of creativity within the industry - I have written about the problem of invisible labour elsewhere (Kuldova, 2016; Kuldova, 2014b) - what interests us here are the skills Indian designers employ as both businessmen and seductive mythmakers. They have grown especially skilled and aware because of the constant pressure to justify and 
Accepted for publication in Thesis Eleven, OnlineFirst July 2015 (printed February 2016), currently waiting for copy-edit

legitimize their position within society. The concept of the fashion designer as a creative artist has been up until the 90s relatively foreign to the world of Indian textile production dominated by artisans, weavers, tailors and factory workers. Even today, with design institutes and fashion weeks in all major cities of the country, Indian designers still struggle with legitimization of their profession. In the process, they became skilled in devising strategies of claiming their superiority and distinction from tailors (Khosla and Johnston, 1996), from both the world of the bazaar, the shopping mall but also from Bollywood's costume design ${ }^{3}$. Having to constantly seek legitimization also meant that they grappled with the question of how to seduce and entice their potential customers and patrons, how to mobilize their affects and turn these into profit. They had to offer something beyond clothes, namely a passionately embraced 'natural habitat of the elite', as one designer framed it. In order to see how their efforts at mobilizing affects and directing passions play out in practice, I shall investigate here two cases of recognized designers, firstly JJ Valaya, the designer to the elites known for his neo-aristocratic opulent aesthetics, and secondly Nitin Bal Chauhan, the designer to the young, aspiring and 'alternative' crowd.

Frédéric Lordon in his Spinozist critique of political economy remarks that "to induce an aligned desire is the perennial goal (...) of all the institutions of capture" (Lordon, 2014: 98). The first question is: what exactly is being captured? Together with Lordon, we could answer that it is the power of acting of individuals. But the second question is: how can an aligned desire be induced, i.e. what are the actual strategies of capture? While Lordon remarks that we tend to be blind to the "immense amount of social labour that is required for producing this 'setting oneself in motion for another" (Lordon, 2014: 4), he remains conspicuously silent on what exactly such 'social labour' and attached 'practices of co-linearization' entail in practice beyond the 'reinvestment of certain acts with joyful affects' or even amorous passions towards the master and his desire, be the master a boss, a fashion designer or a brand. Another question is, however, are we really blind to this social labour? To answer these questions, we must step into the territory of practice, where devising strategies of capture is tightly connected to profit, but before that, let me briefly outline some of the current marketing premises with which the designers also operate.

\section{'Finding a Way Back to Love': Affect and Materiality of Ideology}

Kevin Roberts, the CEO of the advertising agency Saatchi \& Saatchi, has argued that what brands, in order to succeed in contemporary market, need to find their way back to love (Roberts, 2004). A lovemark according to him must tap into people's dreams and create narratives that encourage passion and commitment; it must be loved and respected 'beyond reason'. By mixing the brand message or its 'ethos' into seductive fragrances, design and music, the lovemark is meant to acquire an ambient presence. 
Such immersive ambient spaces are deliberately created to intensify the experience of the customers and to 'influence the unconscious' (Van Praet, 2012), while orienting the induced joyful affects in the direction of the brand and translating them into profit. These strategies are intended to operate covertly and be invisible to the customer. But inducing affects is one thing, directing them another. For the purpose of directing these affects aroused by sensory branding, Roberts proposes the strategy of mythmaking, of framing them within a larger narrative structure of the brand. In practice, his advice means transforming brand ideology into a set of aesthetic, sensory and material experiences and practices set within an ambient environment, accompanied by a compelling narrative. The reorientation of the emphasis from the discursive towards the aesthetic, material, sensory, ambient and affective, suggests an implicit understanding on the part of marketing professionals that ideology, on whose power they rely to sell, is most effective in its practical or material form of everyday acts, rituals and behaviours (Althusser, 2008). It does not matter what people say they believe, so long as they act in alliance with the master-desire of the brand.

While economists still appear reluctant to critically engage with the fantasy of the rational homo oeconomicus driven by calculated self-interest, marketing experts have strayed away, endorsing a vision of an 'irrational market subject', an impulsive shopper thrown around by affects. Fashion designers in particular know well that their trade is not about utility or rational choice, but about carefully designed narratives and production of new ritual venues and events. Designers and marketers have too understood the key insight of 'neurological Spinozism', namely that our relations to out material surroundings are of emotional nature and that without emotion we would be left totally unable to decide (Damasio, 2003; Damasio, 1996). And so, increasing amounts of 'aesthetic work' (Böhme, 2003) go into the production of seductive (BiehlMissal and Saren, 2012) and affective atmospheres (Anderson, 2009) that embed the 'ethos' or ideology of the brand in a chosen space-time rather than bombarding the target audience with direct advertisement (Gobé and Zyman, 2001). Invisible 'atmospheric affects', as we can read in the Journal of Business Research, are a new way of creating value, making profit and gaining a share of the customer (Babin and Attaway, 2000). The social labour of aligning desires of potential consumers with the master-desire of the brand culminates in designing experience. Experience design (XD) has become a serious interdisciplinary subject thought at design colleges across the world, drawing on as diverse disciplines as cognitive science, haptics, ethnography, and so on. The main concern of XD is to induce desired affective and emotional reaction of 'participants' rather than consumers, and to transform these affects into loyal behaviours (Pullman and Gross, 2004). Covert advertising strategies of co-linearization, that attempt to engage audiences seemingly spontaneously or even plant fake grassroots movements (astroturfing), have become part of larger efforts "at 'casualizing' the 
exercise of marketing power" (Serazio, 2013: 30), of inscribing it into everyday material practices. Direct advertising of the 'Uncle Sam' type, who was pointing at us to join the army is being replaced by the self-effacement of advertisers, resulting in a proliferation of strategies of subtle, deliberately invisible consumer governance through which, as Serazio argued, subjects are disciplined (Serazio, 2013) to spend and throw themselves passionately into debt - with joy. And so the US military replaced the old Uncle Sam with a free to download computer game devoid of any explicit injunction to join the army and yet demanding participation while effectively socializing the player in the key army codes. They say that the most powerful PR and marketing is of the invisible kind (Cutlip, 1994), joyfully embraced. But the question is - are we really as blind to the 'invisible marketing' as these experts suggest? And if not, why is it that we still fall for those tricks? I think that we should not underestimate the player here. Even when advertising is deliberately covert, chances are he knows well that the game produced by the US military is intended to 'turn him', but still he plays it and takes pleasure in it. Knowing better does not rob the game of its efficiency, to the contrary - what matters here is the material practice. Knowledge has very limited power to unsettle ideology, to use the Althusserian point, "an ideological formation co-exists simultaneously with the science that breaks with it" (Pfaller, 2005: 110). Or as Slavoj Žižek repeatedly insisted, "it is precisely our 'subversive', 'cynical' distance towards a certain ideology which subjects us to this ideology and allows it to exert its social efficiency" (Pfaller, 2005: 115). In this sense, as we shall see, it is precisely the failure of the advertisers to be covert, as they wish, that subjects us to their tricks.

Anthropology, a discipline specializing in the study of the disjuncture between what people say they do and what they actually do, can provide us with some examples here. In what follows, we encounter two designers and their strategies of capture, very practical, material and ritualistic. Both have their niche market and profit by effectively mobilizing the affects of their devoted customers. This again does not mean that we should imagine these 'devoted customers', who often call the designers their guru and seek his private darshan ${ }^{4}$, as some mysterious dupes that really buy into the whole idea of the designer having magic transformative powers, and who really believe that buying his clothes will fulfil all their dreams. No, to the contrary, the customers are typically well aware that it is a game they play, they act 'as if' the designer had such powers. Take the example of the wealthy women who patronize their favourite designer. They often visit his studios ${ }^{5}$, opulent ambient spaces with luxurious interior, libraries, relaxing music and sultry scent; there they together with the designer indulge in 'celebrating Indianness', in admiring the heritage of the nation, the handwoven silks and embroideries (Kuldova, 2016). The designer tells stories of the maharajas and their tastes in luxury, the women try his clothes while he adjusts little details, telling them how much they resemble the maharanis of the past. Contrasting the studio to the noise, 
pollution and poverty on the streets just outside, the women describe it as an oasis of peace, as a world apart. It becomes an enclosed ritual space, a play-sphere out of the ordinary. The women's visit follow almost a scripted pattern, each time, from the greetings, followed by tea, champagne or whisky on rocks, to socialite gossip, admirations of textile heritage, private updates, selection of pieces, their trying out, fitting discussion, final order, relief, kisses on the cheek, goodbye. The women appear excited, seduced by their own playing of the roles of the designers disciples (in terms of taste) and of his benevolently generous patrons (in terms of buying power). The celebration of the greatness of India, its heritage and future potential appears to particularly enchant the women as they touch embroideries from across India, taking pride in their culture and imagining themselves as its neo-aristocratic leaders. And yet, when the women leave the studio, back in their chauffer driven cars amidst the chaos, heat, and dirt of the streets, they are quick to remark: 'he is only after my money, what theatre he put up again, as if he thinks that I buy all that nonsense about tradition, and this great India, look around, pile of garbage, thank god for air-conditioning!' 6 . The cynical attitude, a pattern rather than an exception, should not detract us here from the material fact that they enthusiastically participate in the ritual and pay up. What is at stake is the capture of the power of acting; hence what matters is the joyful repetitive participation in the ritual. Therefore, neither the designer, typically equally cynical about his own practice, nor the customer, have to share the illusion they enact for that illusion to be effective in practice; instead the ritual appears as if performed for a naïve observer (who might actually believe). We are dealing here with what Robert Pfaller described as 'illusions without owners', i.e. an illusion that no one really believes in (Pfaller, 2014), and yet one that is for that matter no less powerful and no less capable of structuring reality; to the contrary, it functions as a source of pleasure. When played out in the studio, within the enclosed and carefully designed commercial ritual space, the illusion grows in its affective power. The power of play resides in its ability to induce such heightened affect, a 'sacred seriousness', as Johan Huizinga has argued (Huizinga, 1955). Hence, the "psychic intensity produced during play (...) is greater than the extent of affect that appears otherwise in life" (Pfaller, 2014: 74) - talking of the greatness of India within the studio can easily bring tears to customers eyes, but rarely has reality the same capacity to induce affective responses. In real life, the same customers remain indifferent to the nation or to the poor on the streets, yet when at a charity gala they are moved by the screened, carefully edited, stories of the nation's destitute and by theatrical speeches made in their name. This logic of the ambient studio as a gated play-sphere where a ritual unfolds is replicated on a large scale during the elaborately staged fashion shows; there, the commercial ritual makes people move together. 
Accepted for publication in Thesis Eleven, OnlineFirst July 2015 (printed February 2016), currently waiting for copy-edit

\section{JJ Valaya, Indian Business Neo-Aristocracy and the Commercial Rituals}

One thing is the deliberate production of ambient affective atmospheres and spaces, aimed at arousing joyful affects, another thing is how people collectively move within such spaces. It is largely in the collective movement that one embraces the embedded ideologies and brand mythologies. Here the importance of staged events comes most to the fore. As within the private realm of the studio, so at other venues, the profit-oriented designers aim at an ecstatic state of shared excitement capable of aligning people's affects with their master-desire. Hence, fashion shows should be as powerful as a sacred ritual celebration, resulting in 'collective effervescence' (Durkheim, 1965), i.e. an alignment of the affective states that produce a sense of belonging in the participants, a social glue - a "fusion of particular sentiments into one common sentiment" (Durkheim, 1965: 262). While rituals can arouse powerful passions and sway people, these passions need to be directed; affects understood as unbound energy can certainly push us to act, but the question is in what direction they push us. As Yves Citton argued, affects can become effective only when integrated into a narrative structure or a story line that can make sense of our experiences and structure our future paths of action - "we feel in and through stories" (Citton, 2010: 64); an argument reminiscent of the Roberts instructions for creation of lovemarks. Ritualized action here provides similarly structured and patterned frameworks as narrative, taking the form of a lived and felt narrative. As Durkheim pointed out, ritual is essential in the making and remaking of society because it exercises profound force and influence over its participants; hence it must be understood on a collective basis, existing outside our own individual subjectivity and having its own epidemiology. JJ Valaya is one of the designers who brought theatrical fashion shows to perfection, turning them into ritual spectacles culminating in standing ovation. His shows move and charm the audience, but also feed them the narrative of India's greatness and of the greatness of the selected crowd within the gated space, its 'rulers'.

For his Azrak collection inspired by the Ottoman Empire and showcased at the Wills Lifestyle India Fashion Week 2012, JJ Valaya ${ }^{7}$ created a lavish stage set. It featured replicas of a lively Turkish bazaar with trademark chandeliers glittering above it, balconies and domes at the backdrop, musicians Volga Tunca and Christian Chose Vare, belly dancers moving through the scenery and aerial dance performed by gymnasts on fabric trails. While the models walked the ramp like a royalty, the stage was decorated by fake bazaar people, by impoverished embroiderers and craft sellers impersonated by theatre students all painted in blue. Like other top designers for the rich, Valaya's shows are a powerful ritualistic spectacle of elitist distinction steeped in embellishment, ornamentation, texture, detailing, and craft, pregnant with uncontrollable references to past and aristocracy that transgresses any imagined boundaries of time and space. The more the elite business clientele insists that they deserve their wealth based on their 
meritocratic achievement and hard work, the more they seem to buy into the neoaristocratic aesthetics that invokes hereditary privilege and strict hierarchies; the aesthetic reveals here the actual character of 'competitive inequality' in India that more often than not reproduces hereditary privilege (Béteille, 2002). As Valaya regularly proclaims, he is determined to show the world the new India, resplendent with aura of blue-blooded elegance, innovative craftsmanship and modern sensibilities. For his show one year later, The Maharaja of Madrid, Valaya placed on the stage a huge white replica of a Spanish battle ship, hinting at India's conquest of the world. The show culminated with the showstoppers and actors Kabir Bedi, impersonating the phantasmatic Maharaja of Madrid and Kangana Ranaut as the maharaja's daughter. Kabir Bedi walked the ramp proudly, with a touch of royal pomp, inciting the ovation of the audience. Inspired by Spanish nobility, the collection combined elements such as Spanish headgears with heavy Indian royal style. Valaya did away with the first row, replacing it by a lounge with tables covered with wine and cheese. The audience was bedazzled, emotions running high. The neo-aristocratic aesthetic placed within the narrative framework of the conquest of the world by the few on the top has provided the necessary direction to the induced joyful affects. Playing with the notion of conquest by evoking the Spanish or Ottomans and projecting their exploits on the canvas of contemporary and future India, these fashion shows tap directly into the dreams of mastering time and space prevalent among the business elite.

The spectacular show is a result of months of preparations and collaborations with artists, stage designers, musicians, photographers, and most importantly other brands. The whole show depends on numerous sponsorships, no bottle of wine or whisky served is accidental (Kuldova, 2015), all elements of the environment are soaked in more or less visible commercial messages, feeding of each other's power and creating a total ambient environment, a hyper-designed space for the theatrical rituals. Great amounts of social labour go into developing ambient spaces, theatrical fashion ramps and ritual practices that take place within such spaces; from the repeated security checks, seating orders, pre- and post-show gossiping and refreshments, to the after-parties. But while all these events surrounding the shows tend to reproduce internal hierarchies between socialites, celebrities, old wealth, new wealth, wannabes, fashionistas, bloggers, designers, their fans and their patrons, businessmen, promoters, advertisers, models, during the show, if successful, these internal hierarchies for a moment vanish, as the audience collectively indulges in the fantasy staged in front of them. The wish to re-live this powerful moment often structures their future actions - purchases - against their better knowledge that it is intended to do exactly that. Indeed, there are shows that amount to little more than presentations of clothes, lacking the emotional charge and theatricality, sterile in comparison to JJ Valaya's shows that really mobilize the affects of the audience, even against their own will. Even a critical journalist, who normally 
likes to expose the hypocrisy of the New Delhi's elite, told me that she cannot help but fall for the magic of Valaya's shows, 'they just move you, you can't do anything about it, even if you keep trying to resist it ${ }^{\prime 8}$. Framing, wording and editing are as crucial here as ambience, lighting, music and ritualized action - the silence before the fashion show; the anticipation, the male voice resonating in the hall: "please take your seats as we are now about to commence the show, out of respect to designers we urge you to silence your mobile phones...', the silence before the first tones of the music, dancers and artists anticipating the first model, claps, snaps, escalating music, opulent pieces, repeat, showstoppers, the parade, the designer kissed and applauded, standing ovations, admirations, thanks. Every move is rehearsed and timed, nothing is spontaneous or accidental. To increase the power of the show, Valaya dresses not only models, but also people of significant social power; industrialists, pop historians, businessmen, socialites and actors walk the ramp for him and pose in his art photography (Valaya's foray into the world of art was sponsored by Glenfiddich whisky), believing that in the manner of sympathetic magic (Frazer, 2009) his clothes will appropriate the power of the wearer, consequently transmitted onto the buyer. Even outside the show, a lot is invisibly scripted. Indian designers for whom haute couture is the major source of income, as ready-made lines are still limited, commonly provide selected prestigious individuals, typically influential socialites, opinion makers, artists and other glitterati, free design pieces in hope that their prestige will transmit onto the brand. These socialites operate 'undercover' for the designer spreading a good word about him/her, while appearing as genuine customers. This reminds of the turn of the century Parisian couturiers' covert strategies of co-linearization, when they used very similar methods of creating positive reputation for themselves. But even here, knowing about the existence of these strategies does not turn them less effective. I do not know if JJ Valaya really distributes his haute couture pieces freely to key opinion makers, but I heard people say that. No matter the reality, what is interesting is that all who said that and frowned at the practice of being 'covertly' manipulated still owned and flaunted his creations. Again, the awareness about being pushed into certain directions does not prevent the mobilization of affects and their alignment with the master-desire from being effective. This is especially true, when pride and elite belonging are at stake; both are inscribed in material practices and are a matter of maintaining public role and face (Sennett, 1977).

Most of the designers' clients are themselves businessmen, who know well the tricks of the trade, always looking for the next hot thing in marketing. The better they know the kind of strategies of capture used against them when they mingle in the fashion weeks, and yet they let themselves be seduced and shop till they drop. "A 'sacred seriousness', an extreme affective investment occurs here, precisely where there is a 'better knowledge' (...) obedience is often commented with ironic and even self-despising expressions" (Pfaller, forthcoming: 3) such as 'I am such a fool for buying into this, it is 
really a waste you know? One can get the same stuff done elsewhere cheaper, just copy it, same quality, after all it is the craftsmen who do it. Still I buy Valaya". "The mobilizing force of this ideology is considerable (...). Obeying its requirements may bring relief, in some cases pride, often joy or pleasure. Disobedience would cause shame, anxiety or feelings of uncanniness" (Pfaller, forthcoming: 3), especially in a society where maintaining public image and role is imperative.

\section{Echo-Chambers or else Utopian Islands of Plenty}

And there is no escaping these rituals and plays when one belongs to the Indian elite. There is no escaping the gated hyper-designed luxury spaces infused with the same mythology and aesthetics of distinctly Indian elitist and neo-aristocratic exceptionalism. Private farmhouses, five star hotels or palaces and luxury shopping malls, follow the same logic as that of the theatrical stage set of Valaya's show. Elite spaces are 'islands of sanity, security and peace', as one of my Indian friends called them, but also spaces that demand performance and high investment in appearances. They are profoundly utopian spaces where past greatness merges with unlimited world luxuries and the inevitable future conquest of the world by the Indian elite. As John Carey remarked, "paradises, like utopias, tend to be on islands. This may be because they suggest seclusion and purity. But it has also been pointed out that the human foetus is an island. So the island-paradise may reflect man's longing for the protective fluid that once surrounded him" (Carey, 1999). Each venue, including the homes, is gated, protected from the outside world of poverty by actual physical gate, hired guards, and security systems (Brosius, 2009; Waldrop, 2004). To the elite bodies that move from one gated space to another, transported by luxury cars, observing the dusty, polluted, impoverished, and sweaty outside through the darkened window, luxury spaces do function as protective fluid; they are like an echo-chamber where the same ideas resonate, intensified, amplified. But the elite inhabitants are well aware of their own little bubble, of its boundaries, its rules and its rituals. But most of the rituals within these spaces are commercial rituals - fashion shows, exhibition openings, launches of special editions.

In the same way models are often hired to come to elite night clubs and roam around with free drinks merely to beautify the space by their presence, brand messages, opinions, and fashions circulate and become part of the ambience of elite spaces. The ambience itself is a product of collaborating brands, rather than competing brands. Designers have often emphasized to me that coming together enriches everyone; capital accumulates through inclusion, not through exclusion as we are often led to believe. When we step back, we see that JJ Valaya uses the same neo-aristocratic aesthetics, mythology of eliteness and Indian exceptionalism, revitalization of Indian crafts and heritage, artistic nationalism, as most other designers on the top of the hierarchy, all 
heavily supported by 'diverse' alcohol brands (albeit all owned by Pernod Ricard), signing up the same assortment of selected artists and so on. The top segment recites the same mantra, irrespective of the staged individuality of the brands; there is more sameness than difference, more repetition than uniqueness. The interiors of the spaces are designed by the same selected recognized creatives, 'curated' objects and artworks come from the same limited set of artists and brands, clothes worn come from the same designers and few western luxury brands, and so on. Even though being extremely cynical about the whole business of showing off and dressing up, the elite invest great amounts of its power of acting into reproduction of what are largely brand mythologies; they religiously collect premium cards, post images of themselves on Instagram in designer fashion, and hire interior designers for every festival and celebration. Their public face is at stake.

\section{Indian Gen X and the Passionate Madness of Bhootsavaar}

While the huge investment in strategies of ambient governance in the elite segment of the fashion and luxury industry won't surprise us, we often tend to think of alternative, cheaper, youth fashion as somehow different - sometimes as revolutionary, political, be it the hippies or punks, or just anti-establishment, driven by genuine passions. And yet, the few designers who decided to create for the 'Gen-X market' in India use the same strategies of capture and promote very similar nationalist narratives as we have outlined in the case of elite fashion. Only here, the ultimate master-desire of the designers, i.e. their fantasy of making others identical to themselves, becomes more visible. Most designers say they desire to 'create their own world'. We should take this statement literally here. The desire to build a powerful fashion brand is driven by nothing less than a desire to create a niche world of one's own, where the designer's subjects passionately and obediently buy their belonging and place in that world. As often as they speak of building their empires, so often they dream of 'loyal followers' that are 'passionate about the brand'. If we did not know that they were speaking of a fashion brand, we might have thought that the talk is of a religious cult What we see in youth fashion are attempts at using brand rituals and events to form 'new' and commodified 'pseudosubcultural' social groups (in this sense even in case of elitist fashion, rituals serve the same function of group-formation, yet this becomes typically blurred by our perception of the elite in terms of class position).

While in the West the term Gen $X$ is often synonymous with the kids born in the $60 \mathrm{~s}$ and 70 s, the rockers, punks, and so on, in India, the concept of Gen X (' $\mathrm{x}$ ' here stands simply for next) is applied to youngsters between 17-30. The Indian metropolitan Gen X is the digitally connected, post-neoliberal reforms generation comprising largely of the members of urban middle and upper classes. It is the praised and condemned Facebook generation that lives in the globalized India, a generation of India's exemplary 
'consumer citizens'. As such, Gen X, much like the elite, refers to a rather small segment of Indian society, no matter how hyped in the media that equate it with India's shining future (Steele, 2008). While on one hand the hope and the future, on the other, as the cliché goes, compared to the generation of their parents often concerned with saving money and with secure governmental jobs, the youngsters are perceived as great wastrels, defined by their insatiable consumption habits, big dreams and rising debt. It is hard to tell to what degree the hip and cool Gen $\mathrm{X}$ is a creation of marketing and media, or to what degree is it an effect of passionately embracing the master-desire of youth brands and politico-economic ideologues.

Nitin Bal Chauhan is one of the few of India's second generation of fashion designers ${ }^{10}$, who decided to create for the Gen X, with his brand Bhootsavaar ('Possessed'). Nitin's middle class background made him see both the plight of the underprivileged and the charms of elitism, and motivated his desire to create for the 'like-minded crowd'. As he said,

The face of global India and Delhi is a witness to the change that they [Gen $\mathrm{X}]$ are creating. This eclectic mix of professionals lives by their own rules and never forgets to party hard. They are the generation behind huge turnouts at the music festivals and an ever growing night life in the city. They are the reason why more and more youngsters can imagine taking a more challenging path to lead their life. Lot of Bhootsavaar is also bought by teenagers and college students who aspire to strike a different cord with the world around them. Bhootsavaar follows a simple ideology of following your heart. Everyone is mad about something and that feeling and compulsion that comes from within to do that thing is the spark that one needs to acknowledge and respect. ${ }^{11}$

Nitin's desire to create a movement and loyal following consisting of creative young people living according to their passions, but on his aesthetic premises, means that he too has to address the question of how to make people move together and how to provide a relevant framing narrative. While in the elite designer segment we have encountered one type of artistic nationalism that served the purpose, in the world of Bhootsavaar we are confronted with its different flavour. Here the future superpowerdom of India is grounded in the youth of the nation, in its creative potential and madness, with all its aspirations and hunger for life. Within this narrative, it is not the wealthy elite, but the mass of youth that will deliver India's future prosperity and progress (Das, 2000; Kamdar, 2007), while enjoying the benefits of their labour, according to the motto 'work hard, party harder'. It this sense, while the brand aesthetically looks 'subcultural' and 'alternative', it in fact utilizes one of the dominant 
narratives of future India directed largely at the aspiring middle classes. The brand mythology of Bhootsavaar matches the larger narratives of transformation in globalized India and the youth as its driving force, while giving an aesthetic form both to the myths and to the very notions of youth, creativity and passion. As Nitin says, he creates for 'people, who constantly push themselves outside their comfort zone', for people 'from various walks of life - musicians, DJs, artists, graffiti artists, social entrepreneurs, graphic designers, tattoo artists, architects, dancers, theatre artists' and so on. Nitin is as skilled in associating the right brands and collaborating with the right people, as is JJ Valaya. Again, in his practice we observe the same emphasis on (1) engaging audiences through affective ambient environments (2) directing these affects through carefully framed narratives about a distinct emergent class of young creatives and (3) engaging the audiences in ritualized fashion events. In order to achieve maximum impact and in order for his products to appear as spontaneously embraced, as a true grass-root desire, Nitin employs regular people to walk the ramp for him, or to appear in creative fashion presentations staged in clubs and bars. As Nitin says,

when common people who have style or are achievers walk the ramp, I think it creates an aspiration value inside the audience. The ramp no longer belongs to the well-built and beautiful. In fact, the ramp becomes a place for the real, unabashed and talented people. This is the future of fashion and this is the way Bhootsavaar is trying to build a community around it.

Nitin, too, collaborates actively with a whole army of taste and style makers, from designers, artists to musicians, and no less with party and event venues such as the bar Turquoise Cottage in Vasant Vihar, known for its 'underground' and yet privileged invite-only parties. The same gated structures re-appear; the echo-chamber effect is a clear aspiration as new venues and events keep popping up, to which the same people are invited time and again. Nitin wants to see his 'Bhootsavaar family growing'. As of today, it comprises brand endorsers such as music bands like Menwhopause, Reggae Rajahs, Indigo Children, Featherheads, Drop, Minute of decay, Fuzz culture, Mob Marley, Totara Jack, Kern Dalton Collective, and numerous others, break dancers and hip hoppers from the Brooklyn Academy of Dance \& Arts (BADA) in New Delhi, or the graffiti artists, photographers, and so forth. Nitin makes almost weekly online interviews with 'Bhootsavaars', i.e. passionate youngsters working in creative industries, who share their life stories enhancing the larger brand narrative about the rise of contemporary hip, young and wild creative class that lives on its own terms, unburdened by tradition. Within the echo-chamber of the Bhootsavaar family, the myth of the great Indian creative youth that will bring the nation to new horizons is effectively reproduced through very material practices, in events, gatherings, launches, parties, music festivals and interaction in social media environments. 
And yet again, few of the Bhootsavaars do really explicitly buy into the vision. Upon questioning they say things like: 'India is screwed, nothing will ever happen here. Let's just party and forget it.' But still, when on camera, on the ramp or in the interview, they talk of their passion, and their desire to change India - and that is what matters, the material reproduction of the ideology of national greatness that pushes problems, inequalities and misery into invisibility. Of course, privately they tend to distance themselves from such beliefs, saying that it is all just a theatre, and that to succeed they have to play along, maintain their face. They know quite well that the vast majority of young people in India is burdened by traditional roles, poverty, aspirational pressures, feelings of lack and inadequacy, structural violence and so on. They know that those with real holes in their trousers, and not the designed Bhootsavaar holes, are 'expelled' (Sassen, 2014) and not welcome in the 'new' India of shopping malls, IT industry and futuristic smart cities. The problem is not lack of knowledge or ignorance. And yet, in their everyday acts they reproduce precisely those mythologies that expel the impoverished majority. It is precisely here that we see ideology operating at the level of enjoyment that leads to passionate participation, driven by collective libidinal investment. Both versions of the belief in India's future superpowerdom are smoothly incorporated into simple brand ideologies, mobilizing collective affects of the privileged consumers. No matter how different in their aesthetics, both youth and elitist fashion are framed within the same overarching narratives of India's greatness and rise to power, and indeed use identical strategies of capture.

\section{Mobilization of Affects and the Pleasures of Illusions}

In both cases, the strategies of capture employed by the designers utilize the power of play and of rituals set within ambient and gated play-spheres separated from the everyday by gates and 'entry rituals'. Specifically, they utilize the powers of play and ritual to induce heightened affective states (Huizinga, 1955). Here, commercial rituals, as any other rituals, function not only as a social glue (Durkheim, 1965), but also as vehicles of social group formation, be they the elite 'rulers' or 'India's future creative leaders'. Indian culture at large has a great sense for rituals, theatricality and performance in everyday life, dressing up for others, pretending for others, and taking both great pleasure and pride in its own theatrical performances. In this sense, the carefully staged branded rituals feed of this culture that already privileges ritual play, and that is why they are also so effective. Paradoxically, we see that no matter how much the advertisers aim at self-effacement, at complete invisibility, they still cannot fool people into believing that they are not present, and yet what they might perceive as their failure is their victory. Their failure to create 'authentic', 'genuine' or 'real' spaces makes their attempts at seduction effective. The designers' clientele indulge in lavish spending and take pleasure in the fashion shows precisely against their better 
knowledge, perfectly aware that the whole theatre is aimed at their seduction. The same goes for the belief in and carefully cultivated illusion of the greatness of India that is celebrated time and again by the designers in their theatrical shows (Kuldova, 2014a). As Robert Pfaller argued, there "can be no desire without knowing better" (Pfaller, 2014: 93), showing that the extraordinary power of play to fascinate is "bound to one condition", precisely the knowledge that it is 'just' a play - "a player who does not know that the game is play cannot be captured by 'sacred seriousness'. He or she remains trapped in profane seriousness" (Pfaller, 2014: 91). Hence, we remain "absorbed by the illusion of play only if and when we see through it. Knowledge does not help us gain emotional distance - on the contrary, our intellectual distancing pushes us into the throes of the affective captivity of play" (Pfaller, 2014: 93). It is precisely this power of play in service of commercial mythologies that makes people passionately embrace them, while providing them not only with pleasure, but also with collective sense of belonging, pride, self-esteem, even if they hold the whole commercial theatre in great contempt, or precisely because of that.

\section{Notes}

1. Conversations with an anonymous elite fashion designer, New Delhi, winter 2010.

2. The birth of the Indian fashion industry proper dates typically back to the establishment of the National Institute of Fashion Technology (NIFT) in Delhi in 1986, consequently Fashion Design Council of India (FDCI) was established in 1998, and the first fashion week took place in 2000.

3. Even though costume design for Hindi and other regional cinema traditions has been an established staple of the industry since 1930s, a distinction needs to be made between high fashion and costume design for film, even if they utilize each other's power (Wilkinson-Weber, 2013).

4. Darshan translates as sight or vision and is commonly used to describe Hindu worship, the act of seeing and being seen by a deity. Today, darshan, this 'sacred viewing' is being sought even from politicians, activists (think Anna Hazare), Bollywood celebrities, or fashion designers.

5. The observational passages are based on extensive and repetitive observations of the same in designer studios in New Delhi across 2010-2013.

6. From a private conversation following a visit to a renown Delhi based designer, $20^{\text {th }}$ December 2010.

7. JJ Valaya (*1967) is a famous Delhi based couturier, who founded his House of Valaya in 1992 after graduation from NIFT in 1991; he is also the founding member of FDCI.

8. Personal conversation, $9^{\text {th }}$ August 2012.

9. Personal conversation, $12^{\text {th }}$ August 2012. 
10. While the first generation of fashion designers, now in their fifties was trained largely in London and New York, the second generation to which Nitin belongs, has largely been trained in India's fashion institutes (especially NIFT).

11. All following statements are excerpts from an interview with Nitin, $31^{\text {st }}$ August 2014.

\section{Author biography}

Tereza Kuldova is a post-doctoral fellow at the Department of Archaeology, Conservation and History, University of Oslo and a social anthropologist. She has studied the elite segment of the Indian fashion industry and the relations of production. She is currently part of the HERA II Enterprise of Culture research project. Among her recent publications is an edited volume Fashion India: Spectacular Capitalism (2013). In early 2016, her monograph Luxury Indian Fashion: A Social Critique (London: Bloomsbury), will be available. She has also curated and designed an ethnographic museum exhibition Fashion India $(2013$ - 2014) at the Historical Museum in Oslo.

\section{References}

Althusser L (2008) On Ideology. London: Verso.

Anderson B (2009) Affective Atmospheres. Emotion, Space, Society 2: 77-81.

Babin BJ and Attaway JS (2000) Atmospheric Affect as a Tool for Creating Value and Gaining Share of Customer. Journal of Business Research 49: 91-99.

Béteille A (2002) Hierarchical and Competitive Inequality. Sociological Bulletin 51: 327.

Biehl-Missal B and Saren M (2012) Atmospheres of Seduction: A Critique of Aesthetic Marketing Practices. Journal of Macromarketing 32: 168-180.

Brosius C (2009) The Gated Romance of 'India shining': Visualizing Urban Lifestyle in Advertisement of Residential Housing Development. In: Gokulsing KM and Dissanayake W (eds) Popular Culture in Globalized India. London: Routledge.

Böhme G (2003) Contribution to the Critique of Aesthetic Economy. Thesis Eleven 73: $71-82$

Carey J (1999) The Faber Book of Utopias. London: Faber \& Faber.

Ciotti M (2012) Post-colonial Renaissance: 'Indianness', Contemporary Art and the Market in the Age of Neoliberal Capital. Third World Quarterly 33: 637-655.

Citton Y (2010) Mythocratie: storytelling et imaginaire de gauche. Editions Amsterdam.

Cutlip SM (1994) The Unseen Power: Public Relations, A History. Hillsdale, NJ: Lawrence Erlbaum Associates. 
Accepted for publication in Thesis Eleven, OnlineFirst July 2015 (printed February 2016), currently waiting for copy-edit

Damasio AR (1996) Descartes' Error: Emotion, Reason, and the Human Brain. London: Papermac.

Damasio AR (2003) Looking for Spinoza: Joy, Sorrow, and the Feeling Brain. Orlando: Harcourt.

Das G (2000) India Unbound. New Delhi: Viking

Durkheim É (1965) The elementary forms of the religious life. New York: The Free Press.

Entwistle J (2009) The Aesthetic Economy of Fashion: Markets and Values in Clothing and Modelling. Oxford: Berg.

Frazer JG (2009) The Golden Bough: A Study in Magic and Religion. New York: Cosimo Classsics.

Gobé M and Zyman S (2001) Emotional Branding: The New Paradigm for Connecting Brands to People. New York: Allworth Press.

Hoskins TE (2014) Stitched Up: The Anti-Capitalist Book of Fashion. London: Pluto Press.

Huizinga J (1955) Homo Ludens: A Study of the Play-element in Culture. Beacon Press.

Kamdar M (2007) Planet India: How the Fastest Growing Democracy Is Transforming America and the World. Scribner.

Khosla R and Johnston A (1996) Vanguard: Rohit Khosla. New Delhi: India Book House.

Kuldova T (2014a) Designing an Illusion of India's Future Superpowerdom: Of the Rise of Neo-Aristocracy, Hindutva and Philanthrocapitalism. The Unfamiliar: An Anthropological Journal 4: 15-22.

Kuldova T (2014b) Fashion Exhibition as a Critique of Museum Fashion Exhibitions: The Case of 'Fashion India: Spectacular Capitalism'. Critical Studies in Fashion and Beauty 5: 313-336.

Kuldova T (2015) The Indian Cocktail of Value/s and Desire: On Artification of Whisky and Fashion. In: Fuglerud $\varnothing$ and Wainwright L (eds) Objects and Imagination. Oxford: Berghahn Books.

Kuldova T (2016) Luxury Indian Fashion: A Social Critique. London: Bloomsbury. Lordon F (2014) Willing Slaves of Capital: Spinoza \& Marx on Desire. London: Verso.

Pfaller R (2005) Where is Your Hamster? The concept of ideology in Slavoj Zizek's Cultural Theory. In: Boucher G, Glynos J and Sharpe M (eds) Traversing the Fantasy: Critical Responses to Slavoj Zizek. Ashgate.

Pfaller R (2014) On the Pleasure Principle in Culture: Illusions without Owners London: Verso.

Pfaller R (forthcoming) "How is it that we all function without having our own personal police officer at our butts?" The efficiency of ideology and the possibilities of art: an Althusserian account. 
Accepted for publication in Thesis Eleven, OnlineFirst July 2015 (printed February 2016), currently waiting for copy-edit

Pullman ME and Gross MA (2004) Ability of Experience Design Elements to Elicit Emotions and Loyalty Behaviors. Decisions Sciences 35: 551-578.

Roberts K (2004) Lovemarks: The Future Beyond Brands. New York: Murdoch Books Pty Limited.

Sassen S (2014) Expulsions: Brutality and Complexity in the Global Economy. Harvard University Press.

Sennett R (1977) The Fall of Public Man. Cambridge University Press.

Serazio M (2013) Your ad here: the cool sell of guerrilla marketing. New York: New York University Press.

Steele V (2008) Museum Quality: The Rise of the Fashion Exhibition. Fashion Theory 12: 7-30.

Van Praet D (2012) Unconscious Branding: How Neuroscience Can Empower (and Inspire) Marketing. St. Martin's Press.

Waldrop A (2004) Gating and Class Relations: the Case of a New Delhi 'Colony'. City \& Society 16: 93-116.

Wilkinson-Weber CM (2013) Fashioning Bollywood: The Making and Meaning of Hindi Film Costume. Bloomsbury Publishing. 